\title{
Postcolonial Ecocritical Study of "Lullaby" by Silko
}

\author{
Ge Hu \\ School of Foreign Languages of Guangxi University, Nanning, China \\ Email: annahu2033@163.com
}

How to cite this paper: Hu, G. (2021) Postcolonial Ecocritical Study of "Lullaby" by Silko. Open Access Library Journal, 8: e8004.

https://doi.org/10.4236/oalib.1108004

Received: September 24, 2021

Accepted: October 12, 2021

Published: October 15, 2021

Copyright $\odot 2021$ by author(s) and Open Access Library Inc.

This work is licensed under the Creative Commons Attribution International License (CC BY 4.0).

http://creativecommons.org/licenses/by/4.0/

\begin{abstract}
"Lullaby" is a famous short story by native American writer Leslie Marmon Silko. The paper examines a series of traumas Ayah and her family suffer including the loss of land, poverty and spiritual alienation. Ayah's memory of the tribal past reveals her attachment to Indian tradition which is the only comfort and strength left with her. The postcolonial ecocritical study of the short story exposes domestic colonization the Indian people suffer and emphasizes the need to restore Indian cultural tradition to heal traumas and arouse the awakening of Indian national consciousness.
\end{abstract}

\section{Subject Areas}

Literature

\section{Keywords}

Lullaby, Silko, Postcolonial Ecocriticism

\section{Introduction to Postcolonial Ecocriticism and Leslie Marmon Silko's Works}

Postcolonial ecocriticism refers to examining the interrelation between man, nature and environment in postcolonial literature in the context of global integration from the perspective of postcolonialism, and eliminating various forms of logocentrism and hegemony on a global scale in pursuit of universal social justice and environmental justice. Postcolonial ecocriticism is the product from the mutual reference and integration of postcolonialism and ecocriticism, and its establishment means not only the birth of a new literary theory as well as a major turn in postcolonial studies and ecological criticism, but also academia's active thinking and intervention concerning the future of humanity in the trend of globalization. Since the 1990s, critics in different fields have begun to integrate 
and construct various theories from interdisciplinary horizons, and then apply them to the fields of literary and cultural research. The emergence of postcolonial ecocriticism is not only closely related to the academic evolutionary trend mentioned above, but also closely related to the general trend of globalization. In terms of postcolonial theory and ecological criticism, there may be great differences between the two, but there is also considerable consistency between the two in terms of deconstructing logocentrism and their commitment to social justice and environmental justice. In the context of deteriorating global ecological crisis today, the openness and interdisciplinarity between postcolonial theory and ecological criticism make it natural for their mutual reference and integration. As the postcolonial critic Pablo Mukherjee said, postcolonial studies must consider the complex relationship between environmental and political or cultural factors; similarly, ecological criticism must be able to examine ecological issues from social, historical and material perspectives [1] (p. 144). It is in this situation that postcolonial theory and ecological criticism were brought into closer contact in the late 1980s, and after further development and evolution at the beginning of 2000s, postcolonial ecocriticism was established around 2010.

Alongside with N. Scott Momady, James Welch, Louis Erdrich and Paula Gunn Allen, Leslie Marmon Silko is one of the important native American writers in American Indian Literary Renaissance beginning in late 1960s. She was awarded several literary awards because of strong Indian national consciousness and profound Indian cultural flavor in her works. Her first novel Ceremony published in 1977 made her famous and attracted wide critical attention. This novel won her MacArthur Fellowship and she was the first native American writer to receive the honor. In 1994 she was awarded the lifetime achievement award for native American writers. She published Almanac of the Dead in 1991, Gardens in the Dunes in 1999 and The Turquoise Ledge: A Memoir in 2010. Her short story collection Storyteller was published in 1981. Her books deal with various themes of identity, nature, family, love, culture and Indian oral tradition. Her short story "Lullaby" (1974) was anthologized in Best American Short Stories, Norton Anthology of American Literature and Norton Anthology of Women Literature. "Lullaby" traces the painful life memory of a Navajo old woman Ayah: her son Jimmy died in the First World War; her other two children Danny and Ella were forcibly taken away by white people; her husband Chato was fired by the white rancher when he was injured in the leg and unable to work. Interspersed with the past and the present, Silko presents a tough Indian woman who maintains her Indian identity in spite of consecutive tragic events and psychological traumas. The following will examine a series of traumas Ayah and her family suffer from the perspective of postcolonial ecocriticism and analyze Silko's offer of strategy to cope with traumas and maintain Indian identity.

\section{Loss of Land in "Lullaby"}

Before the arrival of the European settlers in North America, the ancient Indians 
had already thrived on this vast continent and created a splendid civilization. Since the white settlers settled down in North America, the Indian land was plundered by various excuses and means, and they were finally forced to live in the barren Indian reservations. In "Lullaby," Ayah and Chato had lost their land and had to work for a white rancher for a meager salary, and endured exploitation and oppression. After Chato fell from his horse and injured his leg, his white boss fired him in spite of his years of hard work, and the poor couple were ordered to move out of their shack to make room for the new work-hand. The couple had to return to their home in Indian reservation which is too barren to grow anything. They had to live on the small relief for Indian people from the government. Chato's years of loyal service were betrayed, which broke his spirit. Ayah used to think naively that if their eldest son, Jimmy, had never died, he could work with his father for the white rancher. With the loss of land, the Indian way of life and ideological values were changed. The loss of land inevitably brings about the change in production and life style, and the Indian civilization mainly based on hunting is also bound to suffer the impact and destruction from the agricultural civilization of white Americans. In the story, Chato had lost the traditional production and life on which his ancestors lived, was tamed by the ideology of agricultural civilization long instilled by the white people, and gradually internalized the white mainstream ideology. Behind the land plunder is the differences and opposition of land ethics between Indian and western civilization. The long-established western dualistic thinking results in the estrangement and opposition between man and land. In the traditional western cultural system, land is a symbol of ownership and private property, an important source of human wealth, an enemy to be subdued and conquered. Instead, in the Indian cognitive system, the earth is the mother of all things, a sacred entity. For Indian tribes, the earth is the source of all things, including human beings, and is fundamental to the maintenance of tribal mythology, feelings, cultural inheritance and historical memory. Therefore, Chato's loss of land reflects the breakdown of Indian ties and estrangement from Indian cultural tradition, and in fact he was culturally rootless and quite adapted to the life of the whites. Loss of land connection not only causes cultural estrangement but also poverty. Losing their land and their spiritual sustenance, some Indian people have abandoned themselves; alcoholism, unemployment, suicide and other social problems frequent Indian reservations. This is true of Chato in the story, who indulged in alcohol drinking and eventually died of winter exposure in drunkenness on the way back from the bar. Alcoholism has become a serious social problem in Indian reservations today, which indicates Indian people's physical and mental torture and at the same time strengthens the stereotype against Indian people as evidence for Indian degeneration and cultural decline, thus leaving each Indian with a heavy historical and realistic burden.

\section{Language Crisis and Spiritual Alienation in "Lullaby"}

The US government forced the Indians to abandon their land by issuing decrees 
such as the Indian Reservation Act and the Native American Relocation Act. Besides the loss of their territory, Indian spiritual home was also invaded by the mainstream white culture. By the 1990s, before the government introduced the Native Language Protection Act, the US government had long adopted ethnic assimilation policies, and English was one of the government strategies to assimilate Indians. The Indians were required to learn English, abandoning their tribal language and lifestyle to integrate into the mainstream white society. In 1887 American Congress Report on Indian Affairs publicly stated that teaching Indian children to learn their own indigenous language will certainly do harm to them, and the first step to lead them to civilization and have them recognize their barbarism is to teach them English [2] (pp. 102-103). At that time the government established specialized Indian educational institutions such as the Carris Indian School in Pennsylvania. The principal of the school publicly declared, "Kill the Indians, save the man" [3] (p. 290). There is no doubt that the US government has deliberately adopted a policy of cultural assimilation to destroy Indian culture.

In "Lullaby," all the major disasters in Ayah's life stem from the intervention of the whites. Jimmy died in World War I while serving for the white government. One important reason for the Indian youth to join the army at that time was to gain the citizenship or leave the reservation to find new opportunities for survival, but Jimmy never returned. To Ayah, her son died in the war started by the whites, which she could not understand. Ayah hated English which took away her family. When the white doctor and police came to take her two young kids Danny and Ella on the excuse of infectious disease, Ayah did not know what they wanted, but she saw that they wanted her to sign those papers. To hurry the white doctor away, Ayah took the pen and signed her name in the three places he pointed to. She thought they would leave when the papers were signed, but her signature gave away her right and allowed them to take her two children away legally. Ironically, her name is the only English word that Ayah could write. Chato taught her to sign her name, which she was proud of. However, Ayah had no idea that knowing a little English was even worse than not knowing English at all, because with her signature, she lost her children forever. For this, "She hated Chato, not because he let the policeman and doctors put the screaming children in the government car, but because he had taught her to sign her name. Because it was like the old ones always told her about learning their language or any of their ways: it endangered you" [4] (p. 3205). Ayah was betrayed by the English papers with her signature, signed to legalize the white doctor taking away her children, the same way as white people cheated Indians into agreements to take away their land in history. Later, the children were taken home several times, but they were all inevitably assimilated by the whites and English, who could no longer communicate with their mother in their mother tongue. Mother tongue is a symbol of a person's identity, the loss of Indian mother tongue symbolizes his separation and estrangement from traditional Indian culture and community, and he becomes someone without cultural root, 
just as Ayah sighed for her two children, "she knew they were already being weaned from these lava hills and from this sky" [4] (p. 3206).

Many Indians naively believe that their situation will improve if they remove the smell of Indian people and are completely integrated into white society. So they began to try their best to adapt themselves to white society, from dress to behavior and ideas [5] (p. 10). Chato could speak English like the white and taught his wife to learn English. But English didn't bring them a decent life. Regardless of years of loyalty and hard work, he was fired after his injury and slow recovery and they were driven away as the white rancher had hired newcomers in his place. Thereafter they lived on a little monthly relief from the government, and Chato quickly took the money for alcohol. Chato's fluent English did not make their family fare any better: English didn't return Jimmy safely from the battlefield, English failed to allow Chato to stop white doctors and police from taking away Danny and Ella, and English failed to give him a stable job and income, a dignified and secure life. Instead, English has left him increasingly alienated from the land and Indian culture, and estranged his wife. To Ayah, he was a stranger. He lost himself between the "two worlds" and moved gradually towards destruction. Through Chato's tragic end, Silko presents the awkward situation of contemporary Indians "living between worlds," culturally marginalized. Some Indians like Chato lost their most basic connection with Indian culture and could find no belonging in the outside world, so they are confused, helpless, lost, and degenerate. The language of the mainstream society-English destroys the spiritual world of the Indians, allowing them to lose their native tongue, experiencing unprecedented spiritual alienation and identity crisis.

\section{Return to Nature and Indian Culture Proposed by "Lullaby"}

Facing the unprecedented spiritual alienation and identity crisis, what is the way out for the contemporary native Americans? Silko gives her own answer in her short story "Lullaby": Indian traditional culture such as lullaby, fairy tales and ancient tribal rituals has incredible magical power, promoting the awakening of Indian consciousness and self esteem. Many other contemporary Indian writers also believe that a return to traditional Indian culture is the only way out of the dilemma of "between the worlds." For example, in The House made of Dawn (1968) by N. S. Momaday, Winter in the Blood (1974) by James Welch and Love Medicine (1984) by Louise Erdrich, the once-alienated protagonists in these novels all found their identity by the return to their community and their re-connection with Indian culture. Silko emphasizes the healing power of nature and Indian culture. In "Lullaby," when Ayah encountered serious setback of life, the ancient Indian culture and shelter of nature could give her the courage and strength to face it bravely. When the white doctors came to take away her children, she ran into the hills with her two kids in panic. She took shelter in nature, where "the sun warmth relaxed her and took the fear and anger away" [4] (p. 3204). As Chato reached the end of his life, Ayah accompanied him: "Ayah saw 
that there was nothing between her and the stars...she breathed the clarity of the night sky; she smelled the purity of the half moon and the stars. He was lying on his side with his knees pulled up near his belly for warmth. His eyes were closed now, and in the light from the stars and the moon, he looked young again" [4] (p. 3208). Ayah sang to her dying husband the lullaby she learned from her grandmother and mother: "The earth is your mother, she holds you. The sky is your father, he protects you. Sleep, sleep. Rainbow is your sister, she loves you. The winds are your brothers, they sing to you. Sleep, sleep. We are together always" [4] (p. 3208). Ayah has suffered so much pain of life, and all her loved ones left her; some Indians are confused, alienated by the white world and could no longer find their way home; Ayah seems to gain some mysterious power in the embrace of nature and receive warmth from the memory of tradition, which is the power of ancient Indian cultural tradition in modern society.

The Indian lullaby contains many natural elements, singing of the Sun, rainbow, wind and Mother Earth. Ayah crooned a lullaby to her dying husband, which could represent the death of traditional Indian world, while the eternal natural elements in the song also suggest that Indian culture could survive along side with the eternal natural world. In the story, Ayah plays the role as the guardian of culture and tradition, as well as the caretaker of her family, not abandoning her husband though she resented him. Through her narration, the Indian oral tradition is preserved. Ayah, close to nature, tough, independent, maintaining her Indian identity in spite of traumas, represents Silko's message for Indian people.

\section{Conclusion}

Through the postcolonial ecocritical analysis of the environment and culture in "Lullaby," we can see the difficult situation of the contemporary Indians who live between the white culture and Indian culture, which results in their spiritual alienation. "Lullaby" narrates Ayah's painful memory of the past and how this trauma-ridden woman receives comfort and power from her memory of tribal life and Indian culture. It is the return to the ancient tribal belief that promotes the awakening of Indian consciousness. Silko suggests in the story that the return to traditional Indian culture is the only way for contemporary Indians to get out of cultural alienation, which in turn will sustain their life instead of being dominated and marginalized by the mainstream culture. This paper studies the domestic colonization native American people suffer and explores how American Indian writers attempt to solve the cultural and existential dilemma for their people. Due to the author's lack of systemic knowledge for Indian culture, further efforts should be made to the study of tribal tradition and Indian cultural elements in the story "Lullaby." The innovation of this paper is to introduce a new perspective-postcolonial ecocriticism into the study of "Lullaby," and explore the importance of land, language and folk tradition in the formation of cultural identity. 


\section{Fund Project}

Undergraduate Teaching Reform Project of Guangxi Higher Education (2020JGB114).

Innovation Project of Guangxi Graduate Education (JGY2020015).

\section{Conflicts of Interest}

The author declares no conflicts of interest.

\section{References}

[1] Pablo, M. (2006) Surfing the Second Waves: Amitav Ghosh's Tide Country. New Formations, 59, 144.

[2] Wang, B. (2005) Selected Reading of American History and Culture. Peking University Press, Beijing.

[3] Divine, R.A., et al. (1990) America, Past and Present. Harper Collins Publishers, New York.

[4] Lauter, P., et al. (1998) The Heath Anthology of American Literature. Houghton Mifflin Company, New York.

[5] Zhu, Z.W. (2006) Multiple Factors in the Localization of American Fiction. Shanghai Foreign Language Education Publishing House, Shanghai. 